\title{
Za nestabilnost spremni? Utjecaj dionika i procesa trećeg sektora na njegove ljudske
}

\section{resurse}

\author{
Danijel Baturina \\ Pravni fakultet, Katedra za socijalnu politiku, Zagreb, Hrvatska \\ e-mail: danijel.baturina@pravo.hr
}

\begin{abstract}
SAŽETAK Ljudski se resursi gledaju kao važan aspekt razvoja organizacija, no u okviru trećeg sektora u Hrvatskoj oni nisu dovoljno istraženi. Ovaj rad za glavni je cilj imao, temeljem rezultata empirijskog kvalitativnog istraživanja, pokazati kakav je utjecaj dionika i procesa koji sačinjavaju treći sektor u Hrvatskoj na ljudske resurse u njemu. Pri tome se analizirala motivacija za rad u trećem sektoru, značaj ljudskih resursa u njemu, njihova uloga te utjecaj koji rad u sektoru ima na njih. Na razini motivacije za uključivanje u treći sektor rezultati sugeriraju da je ona najčešće altruistične prirode. Ljudski resursi u trećem sektoru imaju veće mogućnosti učenja i jačanja svojih znanja te su projektnim radom razvili fleksibilnost. Neki od negativnih utjecaja rada u sektoru odnose se na konstantnu nesigurnost radnog mjesta te određene uvjete rada. Volontiranje još nije dovoljno vrednovano u društvu. Rezultate smo raspravili u svjetlu tekućih trendova razvoja trećeg sektora u Hrvatskoj te suvremenih promjena na tržištu rada.
\end{abstract}

Ključne riječi: treći sektor, ljudski resursi, utjecaj, volontiranje. 


\section{Uvod}

Ljudski se kapital gleda kao važan aspekt razvoja organizacija, ali i utjecaja na radne karijere i životno zadovoljstvo osoba. Kako bi treći sektor ${ }^{1}$ bio obnovljiv resurs ključan za poticanje razvoja održivih i uključivih društava, mora se osloniti na svoje ljudske resurse. S druge strane, on sam specifičnošću organizacije, načina rada, korisnika i područja djelovanja ima značajan utjecaj na vlastite ljudske resurse.

Glavni cilj rada, temeljeno na rezultatima empirijskog istraživanja, pokazati je kakav je utjecaj dionika i procesa koji sačinjavaju treći sektor u Hrvatskoj na ljudske resurse u njemu kroz njihov trenutni položaj i obilježja rada u trećem sektoru. Najprije ćemo se osvrnuti na teorijske uvide o karakteristikama od značaja za ljudske resurse u trećem sektoru te dosadašnja razmatranja utjecaja rada/volontiranja u sektoru. Također, prikazat će se dosadašnji uvidi u položaj ljudskih resursa u trećem sektoru u Hrvatskoj. Daljnji dio rada najprije ce kratko opisati metodologiju istraživanja te zatim prikazati rezultate istraživanja, u kojima ćemo sagledati kako ključni dionici percipiraju motivaciju za rad u trećem sektoru, značaj ljudskih resursa u trećem sektoru, njihovu ulogu te utjecaj koji dionici i procesi trećeg sektora imaju na vlastite ljudske resurse. Rezultate ćemo raspraviti u svjetlu tekućih trendova razvoja trećeg sektora u Hrvatskoj te suvremenih promjena na tržištu rada, dok ćemo u zaključku integrativno dati procjenu stanja ljudskih resursa u trećem sektoru s ogledima o njihovom odnosu prema budućim razvojima sektora.

1 Treći se sektor kao koncept veže uz ideju prema kojoj su osnovne društvene institucije država i tržište, stoga civilno društvo u tom slučaju čini treći sektor (Corry, 2010.). Treći je sektor obuhvatan pojam. Njega zasebno uvode Etzioni i Levitt početkom 70-ih, polazeći od argumenta o neuspjehu tržišta i neuspjeha (rastuće) socijalne države u osiguravanju socijalne zaštite (Lorentzen, 2010.). Etzioni treći sektor vidi kao alternativu državi i tržištu, moguće najvažniju alternativu koja će ne zamijeniti druga dva sektora nego nadopuniti i balansirati njihove važne uloge (Etzioni, 1973.: 315). Glavne prednosti trećeg sektora prepoznaju se u njegovom kombiniranju poduzetničke orijentacije i organizacijske učinkovitosti poslovnog sektora s orijentacijom prema javnom dobru, prisutnom u javnom sektoru (Etzioni, 1973.). Prema definiciji (Salamon i Sokolowski, 2014.) institucionalne komponente trećeg sektora moraju zadovoljiti kriterije da su: 1) organizacije, 2) privatne, 3) samo-upravljajuće, 4) dobrovoljne i 5) u potpunosti ili značajno (prema barem 4 od 5 kriterija navedenih u: Salamon i Sokolowski, 2014.) ograničene u distribuciji dobiti. Takav pristup ima, naravno, svoja ograničenja (značajno više o konceptualizaciji trećeg sektora u: Baturina, 2016.). Koncept trećeg sektora u Hrvatskoj nije prepoznatljiv. Treći je sektor usmjeren prema onim organizacijama koje imaju kapacitete pružanja različitih usluga u području socijalnih službi, obrazovanja, kulture, zdravstva i zaštite okoliša te ekologije. Kao pravne osobe tu pripadaju udruge, zaklade i fundacije, privatne ustanove i neke neprofitne zadruge. Ono što još smatramo trećim sektorom socijalna su poduzeća koja se formiraju u Hrvatskoj i štedno kreditne zadruge (Baturina, 2016.). 


\section{Ljudski resursi u trećem sektoru: obilježja utjecaja $i$ hrvatska iskustva}

\subsection{Ljudski resursi u trećem sektoru}

U ekonomskoj teoriji negdje do 60-ih godina prošlog stoljeća pojavila se teorija ljudskog kapitala (Mincer, 1958.; Becker, 1964.). Becker (1964.)² ga definira kao aktivnosti koje povećavaju poslovne mogućnosti razvijajući najvrjedniji resurs - ljude. On obično uključuje znanje i vještine koje ljudi stječu kao obrazovanje, obuku i radno iskustvo. Međutim može sadržavati pored tih više kognitivnih komponenti i druge fizičke i psihološke osobine kao što su zdravlje, fizičke sposobnosti ili pak motivacija za rad i razvoj (Mušikić i Krulj Mladenović, 2015.). ${ }^{3}$ Ukratko, on je zaliha urođenih ili stečenih znanja ili karakteristika koje radnik ima a koji doprinose njegovoj ili njezinoj produktivnosti (Acemoglu i Autor). ${ }^{4}$

Ljudski se kapital gleda kao važan aspekt razvoja organizacije, ali i utjecaja na radne karijere i životno zadovoljstvo osoba. Ulaganje u ljudski kapital postala je tema ne samo u privatnim organizacijama nego i u organizacijama trećeg sektora. Ljudski resursi koji rade i volontiraju u trećem sektoru, kao nosioci ljudskog kapitala, bit će tematizirani u ovom radu. Dalje ćemo, prije izlaganja empirijskih uvida, promotriti koji su važni aspekti utjecaja dionika i procesa trećeg sektora na zaposlene i volontere u sektoru i kakvi su dosadašnji uvidi u hrvatskom kontekstu.

U ovom dijelu osvrnut ćemo se na dva ključna aspekta. Prvi su neka obilježja pojedinaca koja imaju važnost za (samo)selekciju za rad u tim organizacijama, najviše kroz prizmu motivacije. Drugi je aspekt utjecaj statusa zaposlenja i volontiranja u trećem sektoru na pojedince/ljudske resurse ${ }^{5}$ i razvoj ljudskog kapitala u trećem sektoru.

2 Naravno, od tada su se razvili brojni načini konceptualiziranja ljudskog kapitala. Primjerice, navedimo nešto moderniju definiciju Bontis i sur. (1999.), koji ljudski kapital definiraju kao „ljudski faktor u organizaciji; kombinirana inteligencija, vještine i stručnost koja daje organizaciji njen osebujni karakter. Ljudski elementi organizacije su oni koji su sposobni za učenje, mijenjanje, inoviranje i pružanje kreativnog potiska [...] koji može osigurati opstanak organizacije“.

3 Osim toga kao njegove osnovne komponente mogu se gledati (Bogdanović, 2008.) individualna, koja sadrži navedene kognitivne i druge komponente te kolektivna/socijalna komponenta, koja izvire iz društva.

4 Osim toga danas se sve više govori o intelektualnom kapitalu kao dioniku „nove ekonomije“ (Kolaković, 2003.), u kojoj poduzeća ovise o nematerijalnoj imovini kao što su informacija i znanje. To je ,intelektualni materijal - znanje, informacije, intelektualna imovina, iskustvo - koje može biti iskorišteno za stvaranje bogatstva" (Stewart, 1997., prema Kolaković, 2003.).

5 CIVICUS projekt u jednom od pokušaja oblikovanja pokazatelja za sagledavanje ljudskih resursa organizacija u sektoru sugerirao je, između ostalog, udio volontera u odnosu na plaćeno osoblje, koliko prosječno radnici ostanu na radnom mjestu, je li prestižno raditi u organizacijama u sektoru te postoje li mogućnosti za treninge i druge oblike stručnog razvoja (CIVICUS, 2012.). 
Različiti su radovi naglasili pozitivne utjecaje koji se akumuliraju kod plaćenog osoblja u organizacijama trećeg sektora. Prvi se odnose na motivaciju za rad u sektoru, uključujući veće pro-socijalne motive. Leete (2000.) navodi da je za mnoge neprofitne organizacije uporaba intrinzično motiviranih zaposlenika najbolje rješenje. Osim što dolaze u sektor zbog intrinzičnih motiva oni imaju i visoko zadovoljstvo poslom zbog viših pro-socijalnih motiva (Borzaga i Tortia, 2006.). Zaključuju da intrinzični i relacijski stavovi prema radu vrše najveći utjecaj, dok su radnici koji su motivirani ekonomskim interesima manje zadovoljni. ${ }^{6}$ Lee (2015.) uspoređujući zadovoljstvo poslom menadžera u profitnim i neprofitnim organizacijama nalazi da je ponos na organizaciju najznačajniji faktor u obama sektorima. Dio je intrinzične motivacije koja privlači i zadržava ljudske resurse u neprofitnom sektoru to da su oni više zainteresirani za rad koji će imati značajan utjecaj na društvo i osjećaju da im posao omogućava da postignu osobno značajne ishode. Također češće osjećaju sukladnost vlastitih i vrijednosti organizacije za koju rade (de Cooman i sur., 2011.). Neka istraživanja sugeriraju da postoji veća vjerojatnost da će radnici u neprofitnom sektoru volontirati (Rotolo i Wilson, 2006.), što pokazuje ne samo pristajanje uz misiju sektora nego sugerira i osobne vrijednosti okrenute prema široj društvenoj koristi.

Utjecaj zaposlenja u sektoru često se gleda kroz zadovoljstvo poslom, što je koncept koji se široko koristi ${ }^{7}$. Tortia (2008.) razlikuje materijalne i nematerijalne izvore zadovoljstva. Zaključuje da potonji imaju veću važnost radnicima civilnog društva koje je istraživao. Benz (2005.) pronalazi općenito veću razinu zadovoljstva poslom među osobama koje rade u neprofitnim poduzećima od onih koji rade u profitnom sektoru. ${ }^{8}$ Istraživanja su uglavnom potvrdila da je zadovoljstvo radnika u neprofitnim organizacijama visoko (često veće nego u drugim organizacijskim oblicima), čak i u prisutnosti niže razine plaća (Benz, 2005.; Borzaga i Tortia, 2006.). Također, samo radno okruženje može biti faktor koji ima utjecaj na zaposlene u sektoru. LeRoux i Feeney (2013.) sagledavajući radno okruženje kao značajni aspekt nalaze razliku javnog i neprofitnog sektora. Menadžeri u neprofitnom sektoru u istraživanju imali su veću slobodu da odluče kako raditi, više kontrole oko radnih rasporeda te više prilika za povišice ${ }^{9}$, što su dimenzije koje mogu imati značajan utjecaj na zadovoljstvo poslom.

\footnotetext{
$\mathbf{6}$ No što se tiče odanosti organizaciji, čini se da zadovoljstvo ekonomskim i procesnim aspektima posla ima najveći utjecaj.

7 Taj koncept sadrži dvije različite dimenzije, intrinzičnu i ekstrinzičnu dimenziju zadovoljstva poslom (Fasang i sur., 2007.). Prva ovisi o odnosima s nadređenima, sposobnosti da se iskoriste inicijative i druge kvalitativni aspekti rada. Druga se oslanja na situacijske čimbenike, kao što su plaća, radno vrijeme, sigurnost radnog mjesta i slično.

$\mathbf{8}$ Ali naglašava ograničenje da bi to mogao biti učinak specifičan za industriju jer neprofitne organizacije često djeluju u područjima gdje je ukupno zadovoljstvo poslom veće.

9 Iako postoje distinktivne razlike između sektora, kao dio općeg razvoja prema profesionalizaciji javljaju se i određena razmatranja većeg uvođenja menadžerskih tehnika prikladnijih privatnom sektoru u treći sektor, kao što je model plaćanja prema učinku (Theuvsen, 2004.).
} 
Osim toga organizacije trećeg sektora imaju značajnu ulogu u radnoj integraciji pojedinaca isključenih s tržišta rada i osiguravaju radno iskustvo za mlade ljude, osobe $s$ invaliditetom te dugotrajno nezaposlene osobe, što može imati utjecaj na razvoj ljudskog kapitala, ali i osobnu dobrobit tih populacija (Davister i sur., 2004.). Tako osim aspekta motivacije i zadovoljstva poslom možemo sektor vidjeti i kao prostor pružanja šanse osobama koje su često isključene $s$ tržišta rada.

Osim na one sa statusom zaposlenika, treći se sektor redovito oslanja i na osobe koje djeluju u sektoru u volonterskom statusu. Utjecaj volonterskog statusa na razvoj ljudskog kapitala volontera može se sagledati kroz više dimenzija. Jedan se dio tiče koristi volontiranja za razvoj građanskih i osobnih vještina, dok se drugi dio tiče potencijalnih koristi volontiranja za pronalaženje zaposlenja.

Rochester i sur. (2010., u: Simsa i sur., 2014.) naglašavaju koristi koje imaju volonteri u smislu povećanog zadovoljstva, osobnog postignuća, društvenih mreža i odnosa, vještina, osobnog razvoja, poboljšanih mogućnosti zapošljavanja, mentalnog i fizičkog zdravlja i dobrobiti. Wilson (2000., u: Simsa i sur., 2014.) identificira četiri područja u kojima su istraživanja pokazala pozitivne posljedice volonterskog rada: građanska zauzetost (volonteri su politički aktivni i imaju više povjerenja od nevolontera), antisocijalno ponašanje (volonteri manje „upadaju u nevolje“), zdravlje i dobrobit (volonteri su zdraviji u starosti, imaju bolje samopoštovanje i samopouzdanje te višu razinu zadovoljstva životom) i socioekonomsko postignuće. Postoje također dokazi da volontiranje pozitivno utječe na političko sudjelovanje i angažman (Enjolras, 2015.).

Istraživanja su pokazala da volontiranje može povećati izglede za dobivanje posla ili boljeg posla, te se mnogi pojedinci uključuju u volontiranje u svrhe zapošljavanja. Rezultati istraživanja (Chum i sur., 2015.) pokazuju da za ljude koji žive u mjestima s visokom ekonomskom nesigurnošću i u urbanim sredinama volontiranje poboljšava zapošljivost. Volonteri također vjeruju da im iskustvo volontiranja pozitivno utječe ili će utjecati na mogućnost dobivanja posla. ${ }^{10}$ Kao koristi od volontiranja koje će im pomoći u tome navode povećano povjerenje, a potom radno iskustvo, činjenicu da je volontiranje dokaz o njihovoj motivaciji te na kraju stjecanje specifičnih vještina (Hirst, 2001.). Kada govorimo o volontiranju mladih, istraživanje pokazuje (Newton, Oakley i Pollard, 2011.) da mladi priznaju volonterski rad kao sredstvo za poboljšanje zapošljivosti, koje im omogućuje da razviju generičke i specifične vještine i ojačaju svoj životopis. Također, ono im pruža uvid u buduće karijere te mogućnosti razvijanja mreža koje bi im mogle pomoći u budućim tranzicijama. Mladi su u navedenom istraživanju osjećali da su poboljšali i razvili svoje meke vještine, kao što su komunikacija, timski rad, rješavanje problema, planiranje i upravljanje te posebno upravljanje vremenom. Razvoj osobnih karakteristika, kao što su posvećenost ali i porast samopouzdanja, također je viđen kao važan ishod.

$\mathbf{1 0}$ Iako je povezanost veća za one koji su volontirali više sati i one koji su volontirali iz razloga da poboljšaju šanse za zapošljavanje. 
No nekoliko longitudinalnih studija ne pokazuje jednoznačnu pozitivnu vezu volontiranja s pronalaženjem posla (Kamerāde i Ellis Paine, 2014.; Kamerāde, 2013.). Međutim volontiranje ima druge prednosti, kao što su poboljšavanje vještina i stavova vezanih za zapošljavanje te može biti produktivna alternativa za osobe koje ne mogu osigurati zaposlenje zbog raznih prepreka na tržištu rada. Volontiranje, osim zapošljivosti, može pružati koristi socijalnog uključivanja obogaćivanjem života volontera te ih osnažiti da donesu nove životne izbore (Nichols i Ralston, 2011.). Takoder, kako bi se otvorio put ka zapošljavanju, učinkovitost volontiranja može se poboljšati ako sudionici steknu specifične vještine, znanja i stavove koje poslodavci trebaju. To se dijelom odnosi na treninge, mentorstva i iskustveno učenje, koji bi utjecali na povećanje osobne sposobnosti, prilagodljivosti i zapošljivosti pojedinaca. ${ }^{11}$

\subsection{Stanje ljudskih resursa u hrvatskom trećem sektoru: kontekstualni okvir}

Prije nego što prijeđemo na rezultate istraživanja, u ovom ćemo dijelu rada prikazati kontekst ljudskih resursa u Hrvatskoj što se tiče zapošljavanja, stabilnosti i održivosti ljudskih resursa, edukacije te stanja volontiranja.

Prethodna istraživanja pokazuju da su ljudski resursi i izvori financiranja izvori nestabilnosti za većinu organizacija. Udio organizacija sa stabilnim ljudskim resursima je malen. ${ }^{12}$ Neodrživi i slabi ljudski resursi prepreka su jačem profesionalnom razvoju organizacija trećeg sektora kao i njihovoj održivosti i razvoju (Bežovan i Matančević, 2011.; Matančević i Bežovan, 2013.; Bežovan, Matančević i Baturina, 2016.). ${ }^{13}$ Zapošljavanje novog osoblja u hrvatskom trećem sektoru najčešće se provodi u ovisnosti od projekata, bez razrađenog sustava. Dok, s druge strane, slaba financijska održivost unutar sektora u cjelini otežava zapošljavanje i zadržavanje stručnjaka i obrazovanih mladih osoba.

Udruge često navode probleme s nedostatnim brojem zaposlenih (Juretić i Jakovčić, 2014.; Barada i sur., 2016.) te negativnim stavovima okoline (Juretić i Jakovčić, 2014.). ${ }^{14}$ Kao najznačajnije prepreke nastavku karijere u organizacijama u sektoru ispitanici jednog istraživanja navode loše uvjete rada i stres (Škrbić i Stražnik, 2008.), dok se u istraživanju organizacija civilnog društva koje djeluju u umjetnosti i kulturi

11 Kamerāde (2015.) diskutira da unatoč pozornosti politike i nekim dokazima iz kvalitativnih studija ili kroz-sektorskih anketa, za sada nema dovoljno pouzdanih i dosljednih dokaza o tome poboljšava li volontiranje šanse za zapošljavanje.

12 Pri tome kao ograničenje moramo navesti neadekvatnost službene statistike o broju i promjenama broja zaposlenih u organizacijama u trećem sektoru, što se prepoznaje kao značajan problem (Bežovan i sur, 2016.; Baturina, 2016.).

13 Sagledavajući ljudske resurse sektora prema podacima, udio zaposlenih u neprofitnom sektoru u odnosu na ukupni broj zaposlenih u Hrvatskoj rastao je proteklih godina i kreće se oko 1,3\%. (CERANEO 2014., prema podacima dostupnima u časopisu Udruga.hr).

14 Najčešći negativni stavovi koji su se pojavili jesu da to nije ozbiljan posao, da se radi o poslovima koji su premalo plaćeni, da je rad u udruzi gubljenje vremena. 
navodi i sagorijevanje na osobnoj razini (Barada i sur., 2016.). Osim toga istraživanje (Bežovan i sur., 2016.) sugerira i da niske plaće zaposlenika također predstavljaju poteškoću u održavanju ljudskih resursa.

Dijelom treba razlikovati stanje u većim i manjim organizacijama. Razrađeni sustav zapošljavanja, ali i vođenja evidencije volontera prisutniji je među udrugama koje zapošljavaju veći broj zaposlenika (Nacionalna zaklada za razvoj civilnog društva, 2011.), dok su takvi zahtjevi preveliki za veliku većinu manjih organizacija. Među organizacijama civilnog društva, posebice onim manjima, postoji visoka fluktuacija osoblja i na taj način organizacije gube ljudski kapital u koji su ulagali (TASCO, 2011.; Baturina, 2016.) dovodeći u pitanje održivost svoje profesionalne infrastrukture. Organizacije su slabo podržane od zajednice i svog članstva, što ima negativan utjecaj na organizacijsku održivost.

I u drugim dijelovima trećeg sektora, kao što je socijalno poduzetništvo, stvari ne stoje bitno drugačije. Identificirani su problemi vezani uz financiranje, što je ograničavajući čimbenik pri osiguravanju autonomnosti djelovanja, te nedostatak kapaciteta ljudskih resursa i stručnosti potrebnih za pokretanje socijalnog poduzetništva (Vidović, 2012.; Vincetić, Babić i Baturina, 2013.). Kao novom sektoru, čije inicijative izviru uglavnom iz aktivnosti udruga, posebice mu nedostaje poduzetničkih znanja i vještina kao i specifičnih edukacija. Cjelokupni sektor zadrugarstva kao i socijalne ekonomije zaostaje za tendencijama i razvojem tih sektora u odnosu na razvijenije europske zemlje. Pri tome općeniti problemi razvoja malog poduzetništva, uključujući nedostatak znanja zaposlenika i zadrugara, nedostatak tehnologija, neadekvatne izvore financiranja i probleme u funkcioniranju pravne države, izrazito pogađaju i zadruge (Babić i Račić, 2011.).

Što se tiče razvoja ljudskog kapitala, potrebe za različitim vrstama neformalnog i formalnog obrazovanja u neprofitnim organizacijama jedno su od najizazovnijih područja njihovog razvoja (Pavičić i sur., 2006.). Rast sektora ne samo po obimu i financiranju već i značaju nije pratilo uvođenje programa i tema o civilnom društvu u sveučilišnu nastavu. Za te teme edukacija kroz formalni obrazovni sustav još je uvijek uvelike ograničena (Bežovan i sur., 2011.; Baturina, 2016.). Međutim pokazalo se da na visokoškolskim ustanovama raste broj kolegija ${ }^{15}$ koji tematiziraju područje razvoja civilnog društva (Bežovan i sur., 2011.). ${ }^{16}$ Što se tiče specifičnog obrazovanja, primjerice, tek se nedavno u udžbenicima iz područja marketinga počinje isticati jasna orijentacija prema specifičnostima djelovanja neprofitnih organizacija (Pavičić, Alfirević i Ivelja, 2006.). ${ }^{17}$ Neformalne inicijative prostor su edukacija o različitim

15 Primjerice trenutno na visokim učilištima imamo i nekoliko kolegija koji tematiziraju socijalno poduzetništvo (i ekonomiju).

16 Ustrojena su i dva poslijediplomska specijalistička studija na Ekonomskom i Katoličko bogoslovnom fakultetu Sveučilišta u Zagrebu naziva Marketing neprofitnih organizacija te Management neprofitnih organizacija i socijalno zagovaranje (ustrojen 2004. godine, međutim nije upisao drugu generaciju).

$\mathbf{1 7}$ To je slijedio nešto značajniji doprinos udžbeničkom dijelu, izdavanje udžbenika Osnove marketinga i managementa neprofitnih organizacija (Alfirević i sur., 2013.). 
temama. Isto tako u brojnim je natječajima izberivo financiranje obrazovanja i usavršavanja dionika organizacija trećeg sektora, što organizacije koriste.

Sagledavajući aspekt volontiranja, u Hrvatskoj je do sada provedeno nekoliko istraživanja koja ga tematiziraju. Razina volontiranja uglavnom je niska. Istraživanje uključenosti građana u civilne inicijative u zajednici (Ledić, 2001.) kroz volonterski rad pokazuje da je 43,7\% ispitanika sudjelovalo u nekom vidu volonterskih aktivnosti, dok istraživanje „Volonterstvo i razvoj zajednice“ (Forčić, 2007.) navodi da je tijekom 2005. godine $45,8 \%$ ispitanika sudjelovalo u nekom vidu volonterske aktivnosti. Međutim iza tih brojki krije se niska učestalost volontiranja te nepotpun geografski obuhvat istraživanja. Europsko istraživanje vrijednosti pokazuje nizak stupanj članstva u dobrovoljnim organizacijama te još niži stupanj obavljanja neplaćenog rada za te organizacije. Pri tome se najviše dobrovoljno radi za sportsko-rekreacijske i religiozne ili crkvene organizacije ${ }^{18}$, dok su ostali tipovi organizacija zanemareni. Većina je građana također izjavila da ne obavlja nikakav dobrotvorni rad (Črpić i Zrinščak, 2005.).

Neka istraživanja u Hrvatskoj (Ledić, 2007.) naglašavaju osobno zadovoljstvo kao motivaciju za volontiranje. Istraživanje na studentskoj populaciji ističe da motivacija za volontiranje proizlazi iz vlastitih uvjerenja, vezanih za altruistične motive i pomaganje potrebitima (Pološki Vokić i sur., 2014.). No može se reći da je volontiranje najčešce prigodno, na primjer u humanitarnim akcijama u zajednici. Pokazuje se ograničavajućim i problem kapaciteta organizacija civilnog društva za razvoj kvalitetnih i održivih programa uključivanja volontera (Bežovan i Matančević, 2011.). Istraživanje (Bežovan i sur., 2016.) pokazuje da dio organizacija ima poteškoća pri pronalaženju volontera.

\section{Metodologija istraživanja}

Kako je utjecaj trećeg sektora relativno neistražen fenomen u Hrvatskoj, istraživanje se temeljilo na kvalitativnom istraživačkom dizajnu. Kvalitativne metode po svojoj su prirodi „istražiteljske“ i pogodne za istraživanje fenomena ili koncepata koji su novi i nedovoljno istraženi (Creswell, 2003.). Kvalitativni istraživački dizajn koristio je fleksibilnu istraživačku strategiju (Ritchie i Lewis, 2003.) te uključio analizu dokumentacije policy i zakonskog okvira razvoja sektora te polustrukturirane intervjue s ključnim dionicima, sudionicima istraživanja. ${ }^{19}$ Osim teme ovog rada vezanog za ljudske resurse ispitivale su se i druge dimenzije utjecaja. ${ }^{20}$

18 Slično se pokazalo i u rezultatima EVS-a iz 2008., iako se donekle smanjio postotak ljudi koji dobrovoljno rade u njima (Rimac, 2014.).

19 Osim toga kao dio šireg istraživanja provedeno je šest studija slučaja organizacija u sektoru koje „proizvode“ određeni utjecaj kako bi se sagledali načini na koji se taj utjecaj proizvodi. No one nisu fokus ovog rada.

20 Specifični utjecaj trećeg sektora istraživao se po dimenzijama utjecaja dobrobit i kvaliteta života, socijalne inovacije, građanska zauzetost, osnaživanje, zagovaranje, izgradnja zajednica, ekonomski utjecaji te, konačno, utjecaj na ljudske resurse, koji ovdje tematiziramo. 
Strategija uzorkovanja sudionika za potrebe intervjua temeljila se na namjernom uzorku dionika prema kriteriju „najboljeg informatora“. U uzorak je odabrano 16 ključnih dionika. Oni su odabrani po kriteriju kompetentnosti za temu i iskustva/ uključenosti u sektor, tj. prema tome da imaju što šire uvide u utjecaj organizacija trećeg sektora, da rade i kontaktiraju sa širokim krugom organizacija i da su mnogi od njih kroz provedbena tijela kontinuirano uključeni u evaluacije i praćenje većeg broja projekata i programa organizacija. ${ }^{21}$

Strategija analize podataka analiza je putem nacrta (Milas, 2005.:603), odnosno prema u nacrtu definiranom tematskom okviru dimenzija mjerenja utjecaja. Strategija analize druge razine tema temeljila se na deduktivno-induktivnom procesu definiranja tema, polazeći od tema definiranih nacrtom, međutim ostavljajući prostor za definiranje novih tema iz analizirane građe, što se dijelom i pokazalo kao slučaj. Pri analizi intervjua koristio se višestruki postupak otvorenog kodiranja ${ }^{22}$.

Istraživanje je zadovoljilo etičke kriterije i dobilo dopusnicu nadležnog fakultetskog Etičkog odbora.

\section{Rezultati istraživanja}

Ljudski resursi glavna su snaga svih organizacija, pa i onih u trećem sektoru. O njima uvelike ovisi kakav će i koliki utjecaj organizacija imati. Specifičnosti rada u trećem sektoru oblikuju okruženje u kojem zaposlenici, suradnici, volonteri i drugi uključeni u rad organizacija stvaraju svoje karijere, pokušavaju razviti profesionalne kapacitete i naći zadovoljstvo i svrhu u svom radu.

$\mathbf{2 1}$ Stoga smo u uzorak uključili predstavnike dionika politika u vidu stručnjaka iz ministarstava koja imaju najveći obujam financiranja organizacija trećeg sektora, stoga i aktivno surađuju, dodjeljuju sredstva i evaluiraju projekte. Osim toga uključili smo predstavnike Vladinog ureda za udruge i Nacionalne zaklade za razvoj civilnog društva kao one koji aktivno rade ne samo na alokaciji sredstava nego i razvoju trećeg sektora i imaju moguće ponajviše uvida u njegovo stanje i utjecaj. U uzorak su uključene glavne granske organizacije ili mreže koje imaju uvide u stanje zadruga, socijalnih poduzeća i ustanova. Intervjuirane su i osobe s dugogodišnjim iskustvom rada u sektoru koje su bile ili jesu predstavnici u Savjetu za razvoj civilnog društva, imaju uloge predstavnika organizacija civilnog društva pri Europskom gospodarskom i socijalnom odboru ili su dionici u organizacijama koje su potporni resurs za razvoj trećeg sektora. Na kraju, u uzorak su uključeni po sličnoj logici predstavnici svih regionalnih zaklada koji potiču razvoj trećeg sektora. Oni imaju uvide o razvoju zakladništva, ali zbog svog stalnog financiranja i evaluiranja utjecaja projekata u zajednici imaju informacije o utjecajima širokog kruga organizacija, posebice na lokalnoj razini.

$\mathbf{2 2}$ Iako je uobičajeni postupak da se višestruko kodiranje vrši provjeravanjem strategije kodiranja i interpretacije rezultata od drugog nezavisnog istraživača (Barbour, 2001.), uslijed karaktera istraživanja za doktorsku disertaciju to ovdje nije bilo adekvatno primijeniti. Odvojen postupak kodiranja stoga se odvijao u različitim vremenima od istog istraživača na originalnim zapisima intervjua te su se nakon postupka kodovi uspoređivali i donosila odluka o stupnju njihovog slaganja i konačnom kodu za svaki od kodiranih dijelova građe, čime smo utjecali na povećanje pouzdanosti procesa analize. Nakon toga se dalje konceptualizirala empirijska supstanca i kodovi kako bi se formirale podteme unutar pojedinih dimenzija tematskog okvira. 
Bitno je sagledati koja je uopće motivacija osoba da se uključe u organizacije trećeg sektora te što su neke percipirane prednosti takvog angažmana. Prema percepciji dionika motivacija za uključivanje u treći sektor najčešće je altruistične prirode i ukorijenjena je u osobne vrijednosti individua koje iskazuju želju za pozitivnim društvenim promjenama. Oni pronalaze zadovoljstvo u sudjelovanju u promjenama koje se slažu s njihovim osobnim usmjerenjima i osjećaju se da rade na mjestu na kojem bi željeli. To pronalaženje svrhe, prema mišljenjima dionika, svakako pridonosi većem zadovoljstvu osoba koje rade u sektoru. Oni se ostvaruju u sektoru i vide vrijednost onoga što proizvode.

Tablica 1.

Motivacija za uključivanje i rad u organizacijama trećeg sektora

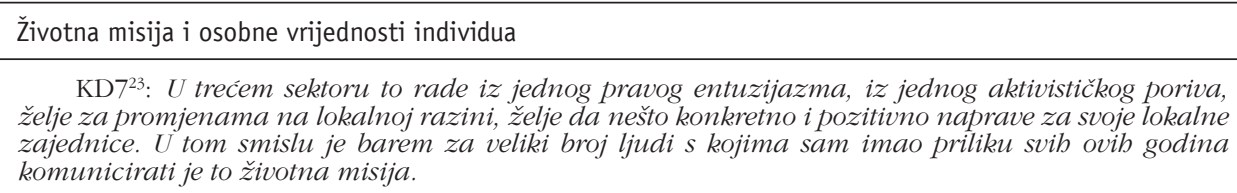

KD16: A mislim, prednosti su prije svega to da se ljudi osjećaju dobro s onim što rade, barem bi to trebalo biti po defaultu tako jer mi se čini da je to jedini nekakav smisao postojanja organizacija civilnog društva, dakle taj neki osobni input, osobni doprinos koji čovjek može osjećati bio on zaposlen po ugovorom, bio honorarac ili volonter. To samo po sebi zapravo, motivacija da ljudi se uključuju u same organizacije civilnog društva i njihove aktivnosti, najčešce ide iz nekih privatnih, osobnih, bilo razmišljanja i stavova ili osobnog iskustva.

KD7: Dakle uz svu tu neizvjesnost, nesigurnost koje nosi zaposlenje u trećem sektoru, rekao bih da veliki dio ljudi ipak ostaje čak $i$ uz nekakve ponude za ozbiljnijim angažmanom u drugim sektorima jer u tome naprosto pronalaze svoju životnu misiju. Jer to je nešto, ta jedna usmjerenost na misiju $i$ tu dimenziju zašto to radite što mnoge mlade privlači da se angažiraju, da se zaposle da svoju karijeru pronađu u trećem sektoru.

Društvene promjene i vrijednosti sektora

KD10: To bib ipak rekla da je ono, različito od osobe do osobe, ono što se najčě̌ce komentira je nekakav osjećaj zadovoljstva što se da nešto $u$ zajednicu. Ta razina nekakva $i$ samoaktualizacija da tako kažem. Druga stvar je vrijednosna. Ja osobno to vidim kao ogromnu prednost. Da su to organizacije koje imaju nekakav vrlo jasan i konkurentan sustav vrijednosti, gdje nije na prvom mjestu kapital, gdje nije na prvom mjestu nekakav novac, nego utjecaj u zajednici, dakle pozitivna promjena, pa mi se u tom smislu čini poticajnije okruženje.

KD6: Al kad osjete nakon mjesec dana kad skuže di su došli, šta rade. I opet taj utjecaj njihov rad ima na neke promjene u društvu onda su motivirani, sretni, znaš energiju dobiju, dobiju taj zalet, zamah. I sigurno možda u tom segmentu i najveći kada govorimo o utjecaju, prvo na ljude.

KD11: Pa prednosti su što većina ljudi radi ono što voli, ima vjeru u to što rade $i$ to im daje nekakvo ispunjenje i osjećaj zadovoljstva i smisla.

KD15: Jer imaju možda neku svrhu, toga što rade, to je možda razlika. Mislim ok, može to biti $i$ $u$ nekoj firmi ali kad, sad me baš jedna kolegica, to nije bitno, to nek ostane među nama, onda radi u jednoj osiguravateljskoj kući $i$ ne vidi smisao toga $i$ sad ce ići raditi u jednu udrugu gdje zaista vidi smisao djelovanja kroz tu udrugu, doprinosi nekom cilju i nekim vrijednostima koje ona poštuje.

Često se percipira da je upravo treći sektor područje za unapređenje vlastitih znanja i vještina u područjima za koje imamo interesa. Ispitanici iskazuju da zaposleni u

23 Ispitanici su označi kodovima od KD1 do KD16 i predstavljaju redom ključnog dionika 1 do ključnog dionika 16. 
sektoru imaju više prilika za educiranje i rast profesionalnih kapaciteta, te u tom smislu unapređenja ljudskog kapitala ne samo pojedinaca već i organizacija i šireg društva. Također, on nudi više i fleksibilnosti te slobode djelovanja u oblikovanju svog rada.

Tablica 2.

Pozitivni aspekti utjecaja: sloboda djelovanja, usvajanje znanja i vještina

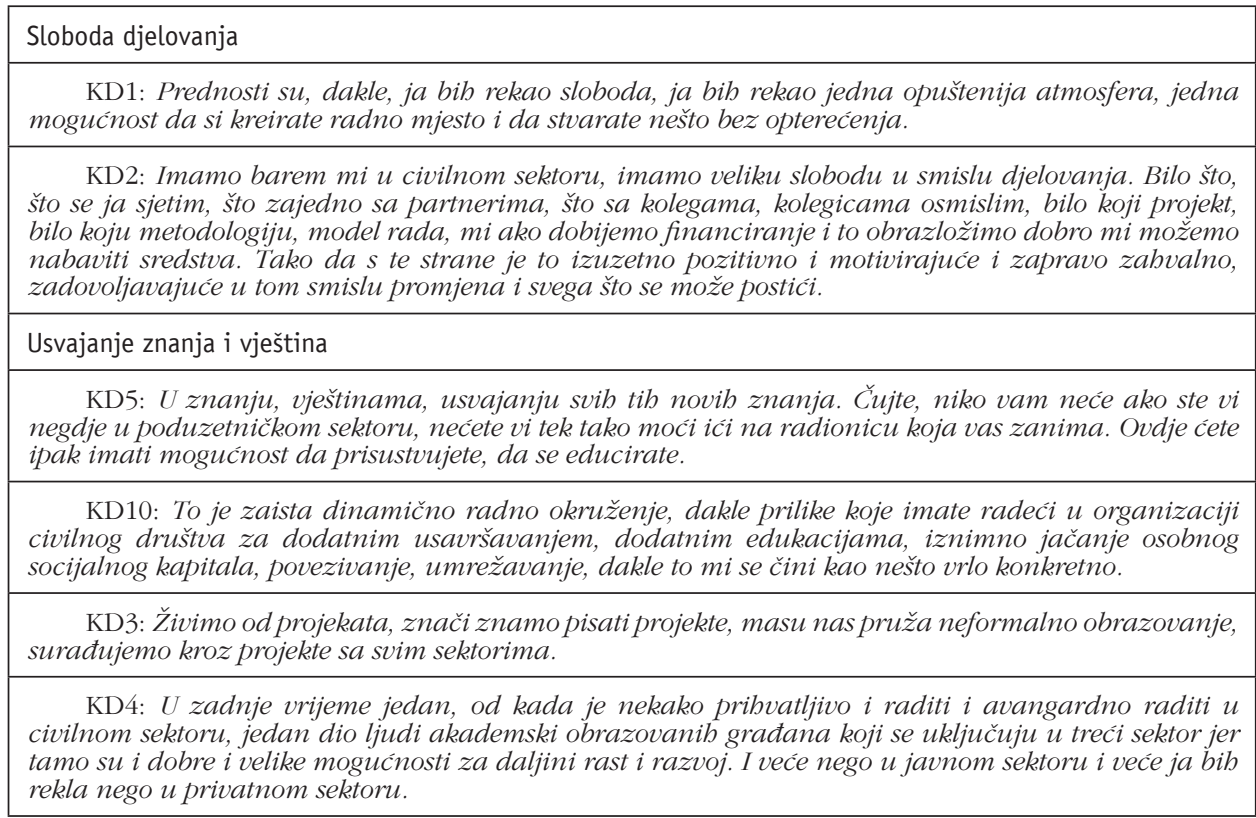

Neki od bitnih negativnih utjecaja rada u sektoru koje ispitanici navode odnose se na konstantnu nesigurnost radnog mjesta. Ona je posljedica manjka kontinuiranih izvora financiranja i permanentnog natjecanja za projekte. U takvim uvjetima osobe mogu osjećati stres, ali i egzistencijalnu neugodu u smislu nemogućnosti planiranja budućnosti. Nesigurnost za sobom povlači i određene rizike fluktuacije radne snage. Jedan od aspekata koji ispitanici uočavaju je „potrošnja“, koja može dovoditi do izgaranja.

Organizacije uslijed inherentne nestabilnosti imaju poteškoće u zadržavanju radne snage. Također, oni koji rade u sektoru osnažuju svoje kapacitete i imaju veći potencijal za zapošljavanje na drugim radnim mjestima. Isto tako, zbog same prirode rada i skupina kojima se često bave, ispitanici navode da rad u sektoru često nema klasično radno vrijeme te da osobe uključene u njega u mnogim slučajevima funkcioniraju kao stalno dostupne. Može se reći da su za jedan dio osoba uključenih u sektor jako zamagljene granice profesionalnog i privatnog života. 
Tablica 3.

Negativni aspekti utjecaja: sigurnost radnog mjesta i uvjeti rada u trećem sektoru

Sigurnost radnog mjesta

KD5: Je, je, jako je stresno. Kad vi gledate upravo ta nesigurnost, to vam je broj jedan. Da li ja svake godine na kraju radne godine moram razmišljati da li cu imati sve djelatnike koji mi čine tim na broju sljedeću godinu jer natječaj nije raspisan ili niste još dobili povrat nekih sredstava koje ste vi uložili. A pogotovo kod ovih nekih europskih projekata. To je izuzetno stresno za organizaciju.

KD7: Dobar dio ljudi naglašavaju da je iscrpljujuće jer rad u sektoru je nesiguran i zabtijeva stalnu borbu iz mjeseca u mjesec, onda iz godine u godinu za prikupljanjem sredstava za dokazivanje u lokalnoj zajednici.

KD6: Prvo, što je nesigurno okruženje. Neshvaćeno okruženje, ti si kontinuirano gradiš poziciju. Gradiš si prostor da radiš. Pogotovo organizacije koje se bave zagovaračkim pitanjima, ljudskim pravima, novim modelima, inovacijama u nekim procesima, promjenama u procesima. Mislim to je pakao, tebe to nitko neće ni financirati, drugo moraš si stvoriti prostor za rad.

KD11: Najočitiji nedostatak, odnosno nešto o čemu se najčešće govori je zapravo ta nesigurnost, ne znam ako radite u udruzi onda radite dok traje projekt. Zapravo je teško računati s tim da ćete moći do mirovine raditi, a $i$ to je nešto što se najčešce spominje.

Fluktuacija radne snage $\mathrm{i}$ „izgaranje“

KD15: Sada trenutno, prvo ova nestabilnost i nekonstantnost, znači u civilnom sektoru nažalost se znaju jako često mijenjati ljudi... Znači ljudski potencijal u udruzi se zna potrošiti, zato jer jednostavno nemaju sredstava za financiranje.

KD11: Znači, mana je sigurno što jako troši, tako da tu vrlo često, bilo bi jednom zanimljivo napraviti istraživanje zdravstvenog kartona ljudi koji su nosioci organizacija trećeg sektora.

KD16: Dogodi se često da ljudi koji se usavrše u nekoj od organizacija civilnog društva, usavrše u svom području koje god to bilo, $i$ možda ga počmu baš poluprofesionalno $i$ na kraju profesionalno ili se onda njihova, dnevna aktivnost svodi na rutinu kao kod svih drugih zaposlenih ili dobivaju neka radna mjesta u drugim strukturama često puta čak $i$ u državnim jer posjeduju iskustva $i$ neka znanja koja nije lako moguće usvojiti.

Uvjeti rada i radno vrijeme

KD11: Ja znam što je naravno mislim da javnost toga uopće nije svjesna, većinu ljudi koji ja znam da su nositelji organizacije trećeg sektora za njib radno vrijeme ne postoji. To su ljudi koji su u uredima ono $u 6-7$ navečer, tu vikendi vrlo često ne postoje, $i$ to isto nije neka održiva situacija.

KD3: Znači, radi se i prekovremeno, pogotovo kad neki izvještaji i pisanje projekata i tako dalje idu, a ti u, ovaj, u javnoj upravi u četiri odlaziš doma jel, zaključaš vrata i tako.

KD2: Ali što se tiče sektora, možda je malo drugačije, u smislu da za neke ljude... recimo Centar za socijalnu skrb će zatvoriti, zaključati će svoj centar, ali moje kolegice u Centru za inkluziju u Puli, oni njih zovu kod god, vikendom se druže s njima, odlaze kod doktora, više se oslanjaju na njih, ... dostupniji smo nego neki koji imaju od do radno vrijeme. Možda je to značajna razlika.

Treći se sektor u velikoj mjeri oslanja na volonterski angažman. Sa strane ljudskih resursa volontiranje u sektoru potencijalno može imati više pozitivnih utjecaja na osobe uključene u volonterske aktivnosti. Ispitanici su pokazali da ima utjecaja na osnaživanje kapaciteta, ali i jedan osobniji pristup koji može biti povoljan okvir za ulazak u profesionalni svijet. Neformalno i formalno učenje, stjecanje vještina i odnos koji postoji između organizacija i volontera stvaraju zasebne doprinose i za volontera i za organizacije. 
Tablica 4.

Pozitivni utjecaji volontiranja

KD5: Isto kao što je djelatnim osobama veća mogućnost educiranja, tako mislim i da volonteri $u$ trećem sektoru imaju mogućnost puno bolje edukacije, puno boljeg usvajanja nekih znanja vještina, alata, imaju mogućnosti.

KD6: Tako da tu vidimo direktan veliki utjecaj, na to mislim možda čak i zbog toga što organizacije civilnog društva puno više gledaju na ljudske potencijale, a ne na ljudske resurse. Dakle ne gledaju na resurs kao na nekakav ono objekt, nego pristupaju subjektu, osobi. I rade na nekoj razini case managementa, ali na nesvjesnoj razini.

KD15: Apsolutno neformalno učenje o nekom području, da i stjecanje iskustva, mislim širenje mreže ljudi s kojima se vi krećete. Ja mislim jednog dana kada dođe do toga da ce se moći nekako vrednovati informalno, neformalno učenje kao što se to vrednuje vani da vam je to prednost kod zapošljavanja, kod daljeg rada, da ce se tada kod nas ojačati taj segment.

KD7: Organizacije koje su bile zadovoljne volonterima $i$ gdje su volonteri stvarno učinili neki važan iskorak $i$ dali dodanu vrijednost pojedinim programima su voljni zadržati te volontere $i$ dati im zaposlenje u svojim organizacijama. Ima kažem niz takvih dobrih primjera.

Utjecaj volontiranja na ljudski kapital volontera ograničen je zbog nekoliko razloga. Pitanje je koliko se značaj volontiranja prepoznaje van sektora, na široj društvenoj razini. U našem slučaju ispitanici dijele mišljenje da na razini društva volontiranje nije dovoljno vrednovano i da njegova promocija može donijeti pozitivne promjene hrvatskom društvu. S druge strane, odgovori sugeriraju da na razini organizacija nedostaje kapaciteta za kvalitetno uključivanje volontera. Iako se brojne oslanjaju na volonterski rad kao ključni resurs, dio još nije osvijestio koliki je potencijal volonterskog rada ili uslijed drugih aspekata rada ne mogu toliko pozornosti posvetiti djelovanju na tom području. Zadnji je razlog manjak prepoznavanja volontiranja od poslodavaca. Ispitanici nalaze da volontiranje nije još uvijek dovoljno ukorijenjeno u našoj praksi u smislu da bi signaliziralo poslodavcima da osobe koje su u njega uključene mogu time usvojiti određene kompetencije i iskustva, koje im mogu biti prednost za zapošljavanje ili korist za samog poslodavca. U tom procesu percipiraju se tek manji pozitivni pomaci te je utjecaj volontiranja ograničen.

Tablica 5.

Ograničavajući aspekti za utjecaj volontiranja za ljudski kapital volontera

Prepoznavanje na društvenoj razini

KD1: Naravno da ne, u toj mjeri ne. Prepoznatlivo je u svom vlastitom krugu. Ukoliko govorimo medu nama, ljudima koji se bave civilnim društvom onda možemo reći da je prepoznatljivo, ukoliko govorimo o ukupnom brvatskom društvu onda možemo reći da nije.

KD6: Nije još osviješteno jednostavno. Daleko da smo pričali ima deset godina to je bilo drugačije, pomaci su vidlivi. Ali daleko je to od toga da se volontiranje smatra logičnim, normalnim korakom u životu svakog pojedinca, da mora imati tu dimenziju ukoliko se smatrate članom zajednice.

KD2: Volonterstvo kao vrijednost $u$ društvu je izuzetno važno $i$ mislim da u Hrvatskoj je sve važnije $i$ u smislu promocije $i$ svega onoga što brvatska mreža volonterskih centara radi. Doprinos civilnog sektoru, udrugama je neizmjeran jer jako puno organizacija, pogotovo onih koji smo govorili na lokalnom nivou se upravo bazira na tome, slobodnom vremenu ljudi koji žele doprinijeti nekakvoj društvenoj promjeni ili javnom dobru ili kroz udruge. Tako da mislim da je, da je izuzetno velik.

KD11: Ogroman, mislim da je općenito volonterstvo kao oblik $i$ življenja $i$ poklanjanja sebe zajednici nedovoljno valorizirano, cijenjeno, što god. Poticano u Hrvatskoj, da smo tu prilično bar mi se čini da smo tu prilično u zaostatku u odnosu na mnoge zemlje. 
Kapaciteti organizacija za uključivanje volontera

KD10: Važnost volontera je jako velika, većina zapravo aktivnosti, mi moramo biti svjesni da organizacije imaju neki dio profesionalnog osoblja, ono plaćenog osoblja, ali svaka organizacija civilnog društva zapravo barem prema nekakvim našim uvidima $30-40 \%$ zapravo svojih aktivnosti provodi zabvaljujući volonterskom doprinosu, tako da bez volontera teško da bi mogli uopće govoriti o trecem sektoru.

KD3: Sada je, sad imamo situaciju da, u principu nemamo dovoljan broj volontera $u$ organizacijama civilnog društva. Ili se broj koji se prikazuje čak bih rekla da je i puno manji stvarni nego onaj koji se prikazuje. Znači taj dio definitivno treba razvijati, a da bi se razvijalo moraju postojati ključni, znači prvo $i$ neka organizacijska spremnost $i$ znanje da bi se taj dio uključio $i$ neke osobe koje ce na tome raditi.

Poticanje volonterstva

KD10: Vrlo malo i gotovo ništa. Znam da se sada rade neka istraživanja na tu temu. I zadnjih par godina se puno govori o vrednovanju volonterskog rada. Rade se sada ove potvrde o kompetencijama, to je jedan od novih instrumenata. Mi smo sada na terenu baš nedavno pratili neke organizacije koje su izdavale te potvrde. Povratna informacija koju dobivamo sa terena je zapravo još uvijek nedovoljno obrabrujuća.

KD9: Prostora za volontiranje uvijek ima, $i$ to je ono što, svi smo negdje otvoreni ali se teško odlučujemo. Samo ja još mislim da kod nas još uvijek volontiranje kod nas kao takvo još nije dobro stimulirano, dobro razrađeno isto ko i cijeli treći sektor. Ne možete ga ni pratiti.

Volonterstvo: prepoznavanje od poslodavaca

KD6: Opet društvene percepcije, društvo veli da ne. Onda dođeš tražit zaposlenje pa te nitko ne pita. Postoje dobri poslodavci u profitnom privatnom sektoru sad koji pitaju i razumiju tu dimenziju. Ali velika većina još uvijek ne.

KD7: Zadnje vrijeme se radilo na tome da se osvijesti poslodavce, različite predstavnike poslovnog sektora o važnosti prepoznavanja rada volontera i davanju prednosti volonterima, osobama koje imaju volonterskog iskustva pri zapošljavanju. To još uvijek nije naravno institucionalizirano, to nije široko pribvaćena praksa u Hrvatskoj ali trend se širi i mislim da dobar dio poslodavaca sigurno pozitivno vrednuju $i$ ovaj aspekt volontiranja.

KD16: Sa razine poslodavaca kako oni prepoznaju iskustvo, može se sad već dokumentirati knjižicama i sličnim dokumentima, međutim bojim se da klasična privreda ili klasična poduzeća gledaju volontiranje kao isključivo kao izvor jeftine radne snage ako ne $i$ besplatne radne snage. Što je ono malo loša reklama za volontiranje.

\section{Rasprava}

Pozitivne utjecaje zaposlenja u trećem sektoru nalazimo u tome da ljudski resursi u tim organizacijama imaju veće mogućnosti učenja i jačanja svojih znanja nego u drugim sektorima, što ih na neki način čini atraktivnijima na globalnom tržištu rada. Visoku izobrazbu i stručnost djelatnika, kao i spremnost na učenje i razvoj nalaze u svom istraživanju i Brajdić Vuković i sur. (2014.). Treći sektor stvara kadar koji prati trendove novih znanja, u korak je s razvojima svojih područja i može donijeti nove poticaje u praksu kroz prenošenje iskustava i znanja iskazujući orijentiranost ka cjeloživotnom učenju. Oni mogu biti prilagodljiviji na promjene, kako su konstantno naviknuti na projektni način rada i spremniji da se uključe u druge sektore, surađuju, izgrađuju partnerstva oko pojedinih pitanja ili interesa. Značaj se u tom pogledu vidi u i kapacitetima ljudskih resursa u sektoru za praćenje politika EU-a i strategija i povlačenju sredstava iz fondova EU-a (Bežovan i Matančević, 2017.).

Kako bi se znanja i kapaciteti mogli unaprijediti, važan je profesionalni razvoj unutar sektora, tj. organizacije za podršku, koje igraju središnju ulogu u osnivanju, pre- 
poznavanju, razvoju i akreditaciji vještina u novim sektorima. U Hrvatskoj postoje tek rijetki primjeri organizacija za podršku. Novim Zakonom o udrugama (2014.) usložnjavaju se odnosi i stavljaju se nove prepreke manjim organizacijama, bez novih oblika podrške. Akreditacija vještina u novim prostorima trećeg sektora daleko je od konteksta našeg iskustva, koji je u nekom pogledu u permanentnom stanju savladavanja osnovnih vještina i izgradnje znanja. Dobar su primjer Centri znanja, koje je delegirala Nacionalna zaklada za razvoj civilnog društva, a koji, iako iznimno vrijedne organizacije u svojim područjima, nisu u pravom smislu resursni centri za širenje vještina i znanja u sektoru. U razmatranju prepreka pokazalo se da dionici percipiraju da znanja i vještine treba kontinuirano graditi i da organizacije tek dijelom to i čine (Baturina, 2016.). Zahtjevi, dijelom nametnuti i fondovima EU-a, idu u smjeru jačanja vještina projektnog menadžmenta i administracije.

Sektor sve više odlikuje povećana profesionalizacija, posebice u pisanju projekata (Bežovan i sur., 2016.), no to, uz nabujalu birokraciju kao prepreku (Bežovan i sur, 2016.), može biti okolnost koja ograničava manje organizacije koje nemaju adekvatne kapacitete. Upravo manje inicijative u lokalnim zajednicama mogu imati utjecaj na lokalno zapošljavanje, posebice marginaliziranih skupina (Baturina, 2016.). Organizacije u sektoru, isto tako, još uvijek nisu iskoristile svoje kapacitete za jačanje suradnje i moglo bi se reći da bi mnogi sinergijski efekti za sektor mogli doći iz proaktivnijeg umrežavanja. ${ }^{24} \mathrm{Za}$ sada se razvoj vještina i znanja više događa na individualnoj razini organizacija.

Ljudski su resursi značajan izazov glede daljnjeg rasta i razvoja organizacija trećeg sektora (Bežovan, 2010.; Bežovan i sur., 2016.). No čini se, prema ograničenim podacima, da zapošljavanje u trećem sektoru raste i da se on vidi kao prostor razvoja ljudskog kapitala nudeći u tom pogledu više prilika nego državni ili privatni sektor. Dosadašnji status trećeg sektora kao sporednog oblikuje se i u percepciji javnih institucija, koje nisu prijemčive za razumijevanje i olakšavanje njegovog djelovanja, što oblikuje i poreznu regulaciju (Bežovan, 2008.) koja dodatno sprečava daljini rast obima aktivnosti i zapošljavanja unutar sektora. Kao primjer nerazumijevanja potencijala sektora možemo navesti nedostatnu razvijenost kombinirane socijalne politike, koja bi se temeljila na procesima hibridizacije sustava, su-proizvodnje usluga i posredničke uloge neprofitnih organizacija (Matančević, 2014.). Nije se osvijestila ni su-vladavina (Pestoff i Brandsen, 2008.), koja odražava pluralizaciju i hibridizaciju pružatelja usluga te podrazumijeva suradnju trećeg sektora i države u pružanju usluga. Takvi razvoji doveli bi do novog zapošljavanja i profesionalizacije trećeg sektora u područjima socijalne politike.

24 Također, među organizacijama se nalazi i onih koje su manje posvećene radu i ostvarivanju svoje misije i čiji su radni ritam, posvećenost i odgovornost prema organizaciji upitni. U takvim slučajevima sumnje u produktivnost ljudskih resursa mogu biti opravdane. KD4: Imamo, da tako kažem, dosta i negativnih iskustava sa uopce sa bilo kakvom vrstom strukturiranog rada u organizacijama civilnog društva. Znači, jedan leđero ritam koji počne u 10 ili 11 sati i završi u tri sata ili nekad u dva. Ili nekad nopće ne dolazak. 
Druga je strane te medalje da organizacije uslijed inherentne nestabilnosti imaju poteškoće u zadržavanju radne snage. Neki od bitnih negativnih utjecaja rada u sektoru koje ispitanici navode odnose se na konstantnu nesigurnost radnog mjesta. ${ }^{25}$ Ona je posljedica manjka kontinuiranih izvora financiranja i permanentnog natjecanja za projekte te potrage za aktivnostima koje bi im mogle donositi financijsku stabilnost. Slaba financijska održivost unutar trećeg sektora u cjelini otežava novo zapošljavanje, zadržavanje obrazovanih stručnjaka i mladih te je prepreka jačem profesionalnom razvoju organizacija u sektoru (Bežovan i Matančević, 2011.; Matančević i Bežovan, 2013.). Ta je situacija posebno naglašena u 2016. godini, koju su odlikovali turbulentni razvoji oko financiranja organizacija od Nacionalne zaklade za razvoj civilnog društva, što je bilo prijetnja financijskom opstanku brojnih organizacija. S druge strane, promjene u političkim strukturama i inherentna nestabilnost koja je proizašla iz toga uzrokovale su kašnjenje brojnih natječaja. Obje situacije imale su efekte stresa na organizacije te uzrokovale i otpuštanje određenog broja radnika uslijed nemogućnosti zatvaranja financijskih konstrukcija. To je moguće zaustavilo trendove rasta zapošljavanja u sektoru, barem po trajnijoj osnovi, no te efekte uvijek treba dodatno istražiti i prikupiti adekvatne podatke.

Isto tako može se reći da su za jedan dio osoba uključenih u sektor jako zamagljene granice profesionalnog i privatnog života, te one u mnogim slučajevima funkcioniraju kao stalno dostupne. Jedan od aspekata koji ispitanici uočavaju je „potrošnja“, koja naslonjena na nesigurnost može dovoditi do izgaranja, na što dijelom upozoravaju i druga istraživanja (Škrbić i Stražnik, 2008.; Barada i sur., 2016.). No s druge strane, kao što ovo istraživanje sugerira, osobe koje djeluju u sektoru imaju veću pro-socijalnu motivaciju prema pozitivnim društvenim promjenama. I druga istraživanja (Barada i sur., 2016.) ističu da zaposleni u civilnom društvu imaju visok osjećaj odgovornosti prema sadržaju koji proizvode i društvenoj zajednici kojoj ga nude.

Brojne su organizacije upravo upućene na volonterski rad za stvaranje dodatne vrijednosti. Mnoge inicijative ne bi započele s radom niti se uspjele održati da ne postoji značajan angažman različitih tipova volontera koji daju svoje vrijeme, znanja i energiju u poticanje razvoja djelovanja organizacija trećeg sektora.

Volontiranje potencijalno može imati više pozitivnih utjecaja u pogledu razvoja kapaciteta i ličnosti pojedinaca uključenih u volonterske aktivnosti. Neformalno i formalno učenje, stjecanje vještina i odnos koji postoji između organizacija i volontera stvaranju zasebne doprinose i za volontera i za organizacije. Što se volontiranja tiče, sugerira se da na razini organizacija nedostaje kapaciteta za kvalitetno uključivanje volontera. One u tom smislu nisu još u potpunosti osvijestile koliki je potencijal volonterskog rada, čemu svjedoče i niske stope volontiranja. No valoriziranje i prepo-

$\mathbf{2 5}$ Jedan od primjera s panela stručnjaka Indeksa održivosti civilnog društva za 2016. godinu: sudionik 5: i da ne govorim da mi imamo ove ugovore na određeno, u daleko većoj količini nego što bi trebalo biti, mi znamo da je to i pitanje rizika siromaštva zaposlenih, vrlo smo u jednoj prekarnoj situaciji, cijeli sektor je prekariziran. (CERANEO, 2016.). 
znavanje volontiranja umnogome govori i o općedruštvenoj orijentaciji i vrijednostima koje prevladavaju. Solidarnost, građanski angažman, proaktivnost i spremnost na djelovanje ugrađeni su u većoj ili manjoj mjeri u tkanje društvenog života svih zajednica. Neki pomaci u institucionalnom prepoznavanju, kao što su Zakon o volonterstvu ili volonterske knjižice, ipak su dosegnuti i oni se tiču infrastrukture (UZUVRH, 2017.). No, primjerice, prostori volonterskog djelovanja u javnim ustanovama još uvijek nisu osviješteni (Bežovan i sur., 2016.). Volontiranje kao šira vrijednost nije dovoljno prepoznato ni poticano u društvu. Također, u Hrvatskoj dominira povezujući socijalni kapital, u kojem su utkani visoki standardi normi i vrijednosti aktivne pomoći primarnim društvenim skupinama (Bežovan i Matančević, 2017.), koji može još dodatno biti potaknut recentnom gospodarskom krizom, koja čini građane nesigurnijima i potiče povlačenje u sebe i primarne zajednice. Dok je za volontiranje nužna otvorenost ka svijetu i novim iskustvima kako bi se ispoljili altruistični motivi.

\section{Zaključak}

U Hrvatskoj je dosad nedovoljno istraženo pitanje utjecaja dionika i procesa trećeg sektora na ljudske resurse u njemu. Stoga je glavni cilj rada bio prikazati i analizirati te utjecaje. Na razini motivacije za uključivanje u treći sektor nalazimo da je ona, prema rezultatima, najčešće altruistične prirode i ukorijenjena je u osobne vrijednosti individua koje iskazuju želje za pozitivnim društvenim promjenama. Što se tiče izgradnje ljudskog kapitala, zaposleni u organizacijama imaju veće mogućnosti učenja i jačanja svojih znanja nego u drugim sektorima, što ih na neki način čini atraktivnijima na globalnom tržištu rada. Oni mogu biti prilagodljiviji na promjene, kako su konstantno naviknuti na projektni način rada i spremniji da se uključe u druge sektore, surađuju, izgrađuju partnerstva oko pojedinih područja ili interesa.

Neki od negativnih utjecaja rada u sektoru koji se vide odnose se na konstantnu nesigurnost radnog mjesta. Ona je posljedica manjka kontinuiranih izvora financiranja i permanentnog natjecanja za projekte. U takvim uvjetima osobe mogu osjećati stres, ali i egzistencijalnu neugodu u smislu nemogućnosti planiranja budućnosti. Borba za održivost organizacija proces je koji nameće nestalnost svakodnevice uključenima u treći sektor i prisiljava ih na kratkoročna životna rješenja i život „u pokretu“ od projekta do projekta. U tom pogledu može negativno utjecati, osim na njihovu financijsku stabilnost, i na odnose koje imaju s bliskim osobama.

Volontiranje još uvijek nije dovoljno prepoznato na široj društvenoj razini. Organizacijama također nedostaje kapaciteta za kvalitetno uključivanje volontera. One u tom smislu nisu još u potpunosti osvijestile koliki je potencijal volonterskog rada. No brojne su organizacije upravo upućene na volonterski rad za stvaranje dodatne vrijednosti, čime jačaju svoj utjecaj, ali i utječu na razvijanje kapaciteta uključenih volontera.

Za ljudske se resurse u trećem sektoru, slijedom rezultata istraživanja, može reći da su na razmeđu. Nesigurna sloboda koju nudi uključivanje u sektor u razmjeru je s mogućnosti izgradnje ljudskih kapaciteta. Obrasci rada u trećem sektoru umnogo- 
me sliče postmodernim uvjetima zapošljavanja, u kojima radna mjesta nisu fiksna, nego se ljudi sve više angažiraju po zadacima ili projektima unovčujući svoja znanja i vještine. U tom je smislu rad u sektoru prototip suvremenih kretanja na tržištima rada, preteča karakteristika koje se sve više mogu očekivati i u drugim sektorima u Hrvatskoj.

Iz istraživačkih rezultata možemo izvući neke preporuke za donosioce politika i praktičare. ${ }^{26}$ Potrebno je razviti trajne, stručne poslove te mogućnosti razvoja karijere kako bi sektor mogao dalje napredovati. No to dobrim dijelom ovisi i o financijskoj održivosti i sklonosti države korištenju kapaciteta sektora, primjerice kroz kombiniranu socijalnu politiku ili inicijative usmjerene ka održivom razvoju, što je javlja kao trend djelovanja trećeg sektora u zapadnim zemljama. Iako se postojanje intrinzične motivacije smatra bitnim za samo(selekciju) za rad u tim organizacijama trećeg sektora, u Hrvatskoj je ona dijelom zasjenjenja konstantnom borbom za održivost, koja često podrazumijeva stresnu ovisnost o prolaznosti projekata na natječajima. U tom smislu bitno je diversificirati financiranje i razvijati inicijative za socijalno poduzetništvo i socijalnu ekonomiju.

Upitna održivost organizacija i sve veći zahtjevi koji se stavljaju pred ljudske resurse moguće će dovoditi do sagorijevanja. Može se očekivati fluktuacija radnika, posebice iz manjih organizacija. Prostor trećeg sektora u kojem građanima već nedostaje navika civilne zauzetosti otvara pitanje koliko će se imati motiva za sudjelovanjem u organizacijama. Stoga dalje treba osnaživati volontiranje na svim razinama, posebno u obrazovnom u sustavu, kao ulazna vrata u treći sektor i mehanizam identificiranja s ciljevima sektora. No dijelom još imamo i bazične prepreke kao što su nepouzdani podaci o broju volontera. Posebno značajan može biti program građanskog odgoja i obrazovanja, koji do sada nailazi na zadršku u provođenju iz manje-više političkih neslaganja. Tu se otvara prostor za prenošenje vrijednosti i upoznavanje sa značajem volontiranja, posebno unutar dijela međupredmetnih tema koje se tiču civilnog društva. No kako bi se ostvario veći utjecaj sektora, ključno je i značajnije uvesti te teme u sveučilišnu nastavu.

Također, rezultati i analize ovog rada mogli bi poslužiti kao zalog aktualiziranja teme ljudskih resursa u trećem sektoru i uvida koji će otvoriti prostore širem (kvantitativnom) istraživačkom interesu za te teme.

26 Koje se dijelom tiču i uvida iz istraživanja FP7 projekta Third sector impact (Bežovan i sur., 2016.). 


\section{Literatura}

1. Acemoglu, D. and Autor, D. (N.A). The Basic Theory of Human Capital, in: Acemoglu, D. and Autor, D. (Eds.). Lectures in Labor Economics. Cambridge, MA Massachusetts: Institute of Technology. https://economics.mit.edu/files/4689. (Pregledano 11. rujna 2017.)

2. Alfirević, N.; Pavičić, J.; Najev, Č.; Matković, Lj. (2013). Osnove marketinga $i$ managementa neprofitnih organizacija. Zagreb: Školska knjiga.

3. Babić, Z. i Račić, D. (2011). Zadrugarstvo u Hrvatskoj: trendovi, pokazatelji i perspektiva u europskom kontekstu. Sociologija i prostor, 49, 191 (3): 287-311.

4. Barada, V.; Primorac, J. i Buršić, E. (2016). Uvjeti rada organizacija civilnog društva na području suvremene kulture i umjetnosti. Zagreb: Biblioteka Kultura nova.

5. Baturina, D. (2016). Utjecaj trećeg sektora na socio-ekonomski razvoj Republike Hrvatske. (doktorska disertacija). Zagreb: Pravni fakultet Zagreb.

6. Becker, G. (1964). Human capital. Chicago: The University of Chicago Press.

7. Benz, M. (2005). Not for the Profit, but for the Satisfaction? - Evidence on Worker Well Being in Non-Profit Firms. Kyklos, 58 (2): 155-176.

8. Bežovan, G. (2008.). Civilno društvo i kombinirana socijalna politika, u: Puljiz, V.; Bežovan, G.; Matković, T.; Šućur, Z.; Zrinščak, S. (Ur.). Socijalna politika Hrvatske. Zagreb: Pravni fakultet Sveučilišta u Zagrebu.

9. Bežovan, G. (2010). Uloga civilnog društva u jačanju kombinirane socijalne politike u Hrvatskoj (istraživački izvještaj). Zagreb: CERANEO - Centar za razvoj neprofitnih organizacija.

10. Bežovan, G. i Matančević, J. (2011). Izgradnja identiteta: izazovi profesionalizacije organizacija civilnog društva. Civicus-ov Indeks civilnog društva u Hrvatskoj (istraživački izvještaj). Zagreb: CERANEO.

11. Bežovan, G. i Matančević, J. (2017). Civilno društvo i pozitivna promjena. Zagreb: Školska knjiga.

12. Bežovan, G.; Ledić, J. i Zrinščak, S. (2011). Civilno društvo u sveučilišnoj nastavi. Hrvatska i komparationa jauna uprava, 11 (1): 173-202.

13. Bežovan, G.; Matančević, J. i Baturina, D. (2016). External and Internal barriers to Third Sector Development-Croatia. Working paper part of work package 5 "External and Internal barriers to Third Sector Development" of the research project entitled "Third Sector Impact".

14. Brajdić Vuković, M.; Ančić, B. i Domazet, M. (2014). Podrška: trajni učinak ili poticajni trenutak? Društveni i gospodarski učinci podrški Nacionalne zaklade za razvoj civilnoga društva. Zagreb: Nacionalna zaklada za razvoj civilnoga društva.

15. Bogdanović, M. (2008). Prilog teoriji ljudskoga kapitala: koja svojstva radne snage treba smatrati bitnim sastavnicama ljudskoga kapitala. EKONOMIJA / ECONOMICS, 15 (1): 45-82.

16. Bontis, N.; Dragonetti, N. C.; Jacobsen, K.; Roos, G. (1999). The knowledge toolbox: a review of tools available to measure and manage intangible resources. European Management Journal, 17 (4): 391-402.

17. Borzaga, C. and Tortia, E. (2006). Worker Motivations, Job Satisfaction, and Loyalty in Public and Nonprofit Social Services. Nonprofit and Voluntary Sector Quarterly, 35 (22): 225-248. 
18. Borgonovi, F. (2008). Doing well by doing good. The relationship between formal volunteering and self-reported health and happiness. Social Science $\&$ Medicine, (66): 2321-2334.

19. CERANEO (2014). Indeks održivosti OCD-a u Hrvatskoj za 2013. godinu. Zagreb: CERANEO.

20. CERANEO (2016). Indeks održivosti OCD-a u Hrvatskoj za 2015. godinu. Zagreb: CERANEO.

21. Chum, A.; Carpenter, S.; Farrell, E.; Mook, L.; Handy, F.; Schugurensky, D.; Quarter, J. (2015). Does geographic context influence employability-motivated volunteering? The role of area-level material insecurity and urbanicity. The Canadian Geographer, 59 (3): 354-368.

22. CIVICUS (2012). Civil society rapid assessment (CSI-RA) indicators. Johannesburg: CIVICUS.

23. Creswell, J. W. (2003). Research Design: Qualitative, Quantitative, and Mixed Methods Approaches. Thousand Oaks, CA: Sage Publications.

24. Črpić, G. i Zrinščak, S. (2005). Civilno društvo u nastajanju. Slobodno vrijeme i dobrovoljne organizacije u Hrvatskoj, u: Baloban, J. (Ur.). U potrazi za identitetom. Komparativna studija vrednota: Hrvatska i Europa. Zagreb: Golden marketing - Tehnička knjiga.

25. Davister, C.; Defourny, J. and Gregoire, O. (2004). Work Integration Social Enterprises in the European Union: An Overview of Existing Models. EMES Working Paper, 04/04.

26. De Cooman, R.; De Gieter, S.; Pepermans, R.; Jegers, M. (2011). A cross-sector comparison of motivation-related concepts in for-profit and not-for-profit service organizations. Nonprofit and Voluntary Sector Quarterly, 40 (2): 296-317.

27. Enjolras, B. (2015). Measuring the Impact of the Third Sector: From Concept to Metrics. TSI Working Paper No. 5, Seventh Framework Programme (grant agreement 613034), European Union. Brussels: Third Sector Impact.

28. Forčić, G. (2007). Volonterstvo i razvoj zajednice. Sudjelovanje građana u inicijativama u zajednici. Istraživanje uključenosti građana u civilne inicijative u zajednici kroz volonterski rad. Rijeka: SMART - Udruga za razvoj civilnog društva.

29. Hirst, A. (2001). Links between Volunteering and Employability: Research Report. London: DfES.

30. Juretić, J. i Jakovičić, I. (2014). Rodna ravnopravnost u vrednovanju rada $i$ zadovoljstva radom u organizacijama civilnoga društva. Zagreb: Prostor rodne i medijske kulture „K-zona“.

31. Kamerāde, D. (2013). Volunteering during unemployment: more skills but where is the job? The Voluntary Sector and Volunteering Research Conference, Sheffield Halam University.

32. Kamerāde, D. (2015) Third Sector impacts on human resources and community. TSRC Working Paper Series No.134. Seventh Framework Programme (grant agreement 613034), European Union. Brussels: Third Sector Impact.

33. Kamerāde, D. and Ellis Paine, A. (2014). Volunteering and employability: implications for policy and practice. Voluntary Sector Review, 5 (2): 259-273.

34. Kolaković, M. (2003). Teorija intelektualnog kapitala. Ekonomski pregled, 54 (11-12): 925-944. 
35. Ledić, J. (2001). Biti volonter/volonterka? Istraživanje uključenosti građana u civilne inicijative u zajednici kroz volonterski rad. Rijeka: SMART - Udruga za razvoj civilnog društva.

36. Ledić, J. (2007). Zašto (ne) volontiramo. Stavovi javnosti o volonterstvu. Zagreb: AED.

37. Lee, Y. (2015). Comparison of Job Satisfaction Between Nonprofit and Public Employees. Nonprofit and Voluntary Sector Quarterly, 45 (2): 1-19.

38. Leete, L. (2000). Wage equity and employee motivation in nonprofit and forprofit organizations. Journal of Economic Behavior \& Organization, 43 (4): 423446.

39. Leeuw, F. and Vaessen, J. (2009). Impact Evaluations and Development. NONIE Guidance on Impact Evaluation. Washington: NONIE-The Network of Networks on Impact Evaluation.

40. LeRoux, K. and Feeney, M. K. (2013). Factors attracting individuals to nonprofit management over public and private sector management. Nonprofit Management \& Leadership, 24 (1): 43-62.

41. Lorentzen, H. (2010). Sector labels, in: Taylor, R. (Ed.). Third Sector Research. New York, Dordrecht, Heidelberg, London: Springer.

42. Matančević, J. (2014). Obilježja modela kombinirane socijalne politike u pružanju socijalnih usluga u Hrvatskoj. (doktorski rad) Zagreb: Pravni fakultet, Sveučilište u Zagrebu.

43. Matančević, J. i Bežovan, G. (2013). Dometi i ključni čimbenici razvoja civilnog društva u Hrvatskoj temeljem tri vala istraživanja. Revija za socijalnu politiku, 20 (1): 21-41.

44. Mušikić, S i Krulj Mladenović, M. (2015). Ljudski kapital kao kvalitativna komponenta privrednog rasta i razvoja. Rad redstavljen na: Synthesis 2015 - International Scientific Conference of IT and Business-Related Research. doi:10.15308/ Synthesis-2015-459-462.

45. Milas, G. (2005). Istraživačke metode u psibologiji $i$ drugim društvenim znanostima. Zagreb: Naklada Slap.

46. Mincer, J. (1958). Investment in human capital and the personal income distribution. Journal of Political Economy, 66 (4): 281-302. doi: 10.1086/258055.

47. Nacionalna zaklada za razvoj civilnog društva (2011). Procjena stanja razvoja organizacija civilnoga društva u Republici Hrvatskoj. Izvještaj istraživanja u 2011. godini. Zagreb: Nacionalna zaklada za razvoj civilnog društva.

48. Newton, B.; Oakley, J. and Pollard, E. (2011). Volunteering: supporting transitions. London: Insprired, the National Young Volunteers' Service.

49. Nichols, G. and Ralston, R. (2011). Social Inclusion through Volunteering: The Legacy Potential of the 2012 Olympic Games. Sociology-the Journal of the British Sociological Association, 45 (5): 900-914.

50. Pavičić J.; Alfirević, N. i Ivelja, N. (2006.). Oblici i mehanizmi potpore i suradnje s neprofitnim organizacijama U Hrvatskoj. Zbornik Ekonomskog fakulteta u Zagrebu, 4 (1): 217-238.

51. Pestoff, V. and Brandsen, T. (2008). Co-production: The Third Sector Services and the Delivery of Public Services. London, New York: Routledge.

52. Pološki Vokić, N.; Marić, I. i Horvat, G. (2014). Motivacija za volontiranje - jesu li motivi za volontiranje povezani sa spolom, ličnosti i područjem studiranja? Revija za socijalnu politiku, 20 (3): 225-252. 
53. Rimac, I. (2014). Komparativni pregled odgovora u anekti Europska studija vrijednosti 1999. i 2008., u: Baloban, J.; Nikodem, K. i Zrinščak, S. (Ur.). Vrednote u Hrvatskoj i u Europi: Komparativna analiza. Zagreb: Krščanska sadašnjost. Katoličko bogoslovni fakultet Sveučilišta u Zagrebu.

54. Ritchie, J. and Lewis, J. (Ed.) (2003). Qualitative Research Practice: A Guide for Social Science Students and Researchers. London: SAGE Publications Ltd.

55. Rotolo, T. and Wilson, J. (2006). Employment sector and volunteering: The contribution of nonprofit and public sector workers to the volunteer labor force. The Sociological Quarterly, 47 (1): 21-40.

56. Simsa, R.; Rauscher, O.; Schrober, C.; Moder. C. (2014). Methodological Guideline For Impact Assessment, TSI Working Paper Series No. 1. Seventh Framework Programme (grant agreement 613034), European Union. Brussels: Third Sector Impact.

57. Simsa, R.; Rauscher, O.; Schrober, C.; Moder. C. (2014). Methodological Guideline For Impact Assessment, TSI Working Paper Series No. 1. Seventh Framework Programme (grant agreement 613034), European Union. Brussels: Third Sector Impact.

58. Škrbić, N. i Stažnik, M. (2008). Odgovornost i predanost pod stresom»-Analiza stanja zaposlenosti mladih i planiranja dugoročne profesionalne karijere u organizacijama civilnog društva $u$ RH. Zagreb: DIM - Udruga za građansko obrazovanje i društveni razvoj

59. TASCO (Technical Assistance for Civil Society Organisations in the IPA Countries). (2011). Needs Assessment Report - Croatia. Zagreb: TACSO.

60. Theuvsen, L. (2004). Doing better while doing good: Motivational aspects of pay-for-performance effectiveness in non-profit organizations. Voluntas: International Journal of Voluntary and Nonprofit Organizations, 15 (2): 117-136.

61. UZUVRH (2017). Nacrt Nacionalne strategije stvaranja poticajnog okruženja za razvoj civilnoga društva 2017. - 2021. Zagreb: Ured za udruge Vlade Republike Hrvatske.

62. Vidović, D. (2012). Socijalno poduzetništvo u Hrvatskoj. Doktorska disertacija. Zagreb: Filozofski fakultet, Sveučilište u Zagrebu.

63. Vincetić, V.; Babić, Z. i Baturina, D. (2013). Definiranje područja i potencijal razvoja socijalnog poduzetništva hrvatske u komparativnom kontekstu. Ekonomski pregled: mjesečnik Hrvatskog društva ekonomista Zagreb, 64 (3): 256-278. 
Danijel Baturina

Faculty of Law, Social Policy Chair, Zagreb, Croatia

e-mail:danijel.baturina@pravo.hr

\title{
Ready for Job Insecurity? The Impact of Third Sector Stakeholders and Processes on their Human Resources
}

\begin{abstract}
Human resources are seen as an important aspect of the development of organizations, but they are not sufficiently explored within the third sector in Croatia. Based on the results of empirical qualitative research, the main goal of this paper is to show what kind of impact third sector stakeholders and processes in Croatia have on human resources in it. We have analyzed the motivation for working in the third sector, the importance of human resources in the sector, their role and the impact that work in the sector has on them. At the level of motivation for the engagement in the third sector, the results suggest that the most common reason is altruism. The third sector human resources have greater opportunities to learn and strengthen their knowledge and have developed flexibility through project work. Some of the negative effects of the work in the sector are related to constant job insecurity and certain working conditions. Volunteering is not yet sufficiently valued in society. The results are discussed in the light of current trends in the development of the Croatian third sector and recent changes in the labour market.
\end{abstract}

Key words: third sector, human resources, impact, volunteering. 